\title{
Mees' lines in high altitude mountaineering
}

\author{
Avinash Aujayeb ${ }^{\bullet}$
}

Acute Medicine and Respiratory Department, Northumbria Healthcare NHS Foundation Trust, North Shields, Newcastle, UK

\section{Correspondence to}

Dr Avinash Aujayeb, avinash.aujayeb@nhct.nhs.uk

Accepted 27 February 2019

\section{DESCRIPTION}

Mees' lines (MLs) were first described in 1919 and are white lines of discolouration that run across finger or toe nails. They are also called leukonychia striata. ${ }^{1}$

A 27-year-old man presented with lines across his fingernails, across both hands. The lines were non-blanchable and the nails had no apparent depression. His toes were not affected. Figure 1 shows classic Mees' lines. He was a never smoker, took no medications and had no relevant medical history.

Six weeks previously, he had participated in a high-altitude mountaineering expedition in the Pakistani Karakorum range to a mountain called Spantik (figure 2), the summit of which was at $7031 \mathrm{~m}$. The expedition acclimatised from base camp situated at about $4000 \mathrm{~m}$ of altitude and spent 21 days on the mountain thereafter. He did not use any medications to aid acclimatisation. He did not reach the summit, and turned back at $6900 \mathrm{~m}$ due to a combination of hypothermia and exhaustion. When back at sea level, he noted that he had lost 8 $\mathrm{kg}$ of weight. He quickly regained that weight and remained well with no medical problems. The lines moved distally with nail growth and eventually disappeared.

Differential diagnoses of such nail changes include Beau's lines, Muehrcke's lines and Mees' lines. All the above nail changes are due to a temporary cessation of nail growth. ${ }^{12}$

Beau's lines are white grooved lines traversing the width of the nails, occurring due to trauma, malnutrition, infection, systemic illness and chemotherapy agents. They are associated with grooving and depression in the nails. Muehrcke's lines are a set of one or more pale transverse bands which are not grooved and strongly associated with hypoalbuminaemia. Muehrcke's lines do not move and eventually fade away. ${ }^{12}$ Mees' lines are associated with heavy metal poisoning and chemotherapy and the nails do not become grooved. ${ }^{12}$

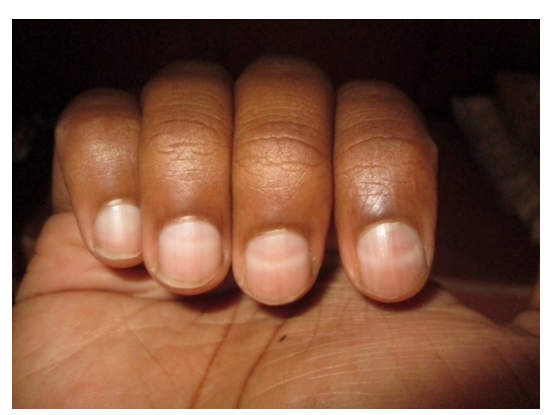

Figure 1 Picture showing white transverse lines across finger nails, taken 6 weeks after spending 3 weeks at high altitude.

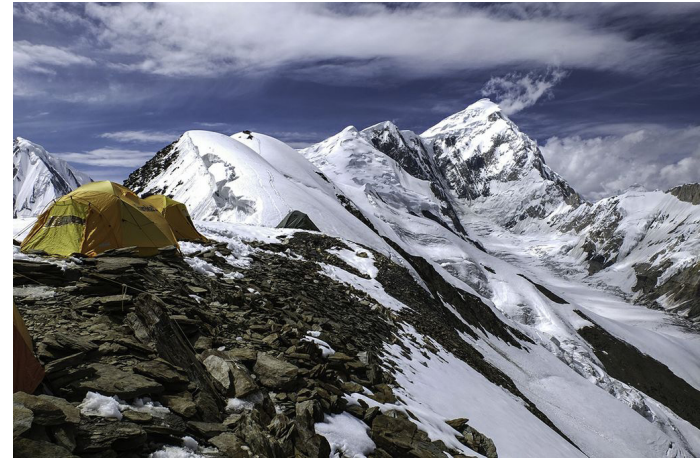

Figure 2 Picture showing Spantik, in the Pakistani Karakorum.

A wide variety of nail changes are associated with high altitude mountaineering and have been attributed to a reduction in iron stores, local trauma, cold exposure, the side effects of medications taken at altitude and a hypobaric environment. ${ }^{3-5}$ By definition, extreme altitude was reached at $6900 \mathrm{~m}$, where the inspired $\mathrm{PaO}_{2}$ of oxygen is about $39 \%$ compared with sea level. ${ }^{6}$ There are also significant metabolic adaptations at such heights with augmentation of basal metabolic rate, decreased oxygen in peripheral metabolic tissues, reduction in maximal ventilation, increased glucose dependency and lactate accumulation during exercise. Any effort requires more energy and weight loss is extremely common. ${ }^{7}$

Management of MLs and any of the other nail changes described above require treatment of the underlying systemic problem or cessation of offending medications, although they are more of a cosmetic than a medical issue. Their appearance in a normally fit and well individual should prompt a full history and examination, including recent relevant physical activity and travel. Nail growth is approximately $3 \mathrm{~mm} / \mathrm{month}$ and thus, the distance from the proximal nail fold to the line can help develop a timeline of any potential illness. ${ }^{1-4}$

Learning points

- Mees', Beau's and Muehrcke's lines are all transverse lines seen on finger or toe nails.

- Only Beau's lines are grooved.

- Mees' and Beau's lines move distally with nail growth.

- Mees', Beau's and Muehrcke's lines are associated with systemic illness, trauma, poisoning, medications and high-altitude mountaineering.

- High-altitude mountaineering is associated with significant metabolic demands and hypoxia. 
Images in...

Contributors $A A$ is the patient. AA wrote and researched the manuscript.

Funding The authors have not declared a specific grant for this research from any funding agency in the public, commercial or not-for-profit sectors.

Competing interests None declared.

Patient consent for publication Obtained.

Provenance and peer review Not commissioned; externally peer reviewed.

\section{REFERENCES}

1 Huang TC, Chao TY. Mees lines and Beau lines after chemotherapy. CMAJ 2010;182:E149.
2 Zaiac MN, Walker A. Nail abnormalities associated with systemic pathologies. Clin Dermatol 2013;31:627-49.

3 Bellis F, Nickol A. Everest nails: a prospective study on the incidence of Beau's lines after time spent at high altitude. High Alt Med Biol 2005;6:178-80.

4 Windsor JS, Hart N, Rodway GW. Muehrcke's Lines on Mt. Everest. High Alt Med Biol 2009;10:87-8.

5 Burtscher M, Likar R. Leukonychia following high altitude exposure. High Alt Med Biol 2002;3:93-4.

6 West JB. Prediction of barometric pressures at high altitude with the use of model atmospheres. J Appl Physiol 1996;81:1850-4.

7 Hill N, Stacey M, Woods D. Energy at High Altitude. J R Army Med Corps 2011;157:43-8.

Copyright 2019 BMJ Publishing Group. All rights reserved. For permission to reuse any of this content visit

https://www.bmj.com/company/products-services/rights-and-licensing/permissions/

BMJ Case Report Fellows may re-use this article for personal use and teaching without any further permission.

Become a Fellow of BMJ Case Reports today and you can:

- Submit as many cases as you like

- Enjoy fast sympathetic peer review and rapid publication of accepted articles

- Access all the published articles

Re-use any of the published material for personal use and teaching without further permission

For information on Institutional Fellowships contact consortiasales@bmjgroup.com

Visit casereports.bmj.com for more articles like this and to become a Fellow 